\title{
Nanostructured Si-C Composites As High-Capacity Anode Material For All-Solid-State Lithium-Ion Batteries
}

\author{
Stephanie Poetke, ${ }^{[a, b]}$ Felix Hippauf, ${ }^{[b]}$ Anne Baasner, Susanne Dörfler, ${ }^{* b]}$ Holger Althues, ${ }^{[b]}$ Stefan \\ Kaskel[a,b]
}

[a] S. Poetke, Prof. Dr. S. Kaskel

Department of Inorganic Chemistry I

Technische Universität Dresden

Bergstraße 66, 01069 Dresden, Germany

[b] S. Poetke, Dr. F. Hippauf, Dr. S. Dörfler ${ }^{*}$, Dr. H. Althues, Prof. Dr. S. Kaskel

Department of Surface and Battery Technology

Fraunhofer Institute for Material and Beam Technology (IWS)

Winterbergstraße 28, 01277 Dresden, Germany

E-mail: susanne.doerfler@iws.fraunhofer.de

Supporting information for this article is given via a link at the end of the document

\begin{abstract}
Silicon carbon void structures $(\mathrm{Si}-\mathrm{C})$ are attractive anode materials for Lithium-ion batteries to cope with the volume changes of silicon during cycling. In this study, Si-C with varying $\mathrm{Si}$ contents (28 - $37 \%$ ) are evaluated in all-solid-state batteries (ASSBs) for the first time. The carbon matrix enables enhanced performance and lifetime of the $\mathrm{Si}-\mathrm{C}$ composites compared to bare silicon nanoparticles in half-cells even at high loadings of up to $7.4 \mathrm{mAh} \mathrm{cm}^{-2}$. In full cells with nickel-rich $\mathrm{NCM}\left(\mathrm{LiNi}_{0.9} \mathrm{Co}_{0.05} \mathrm{Mn}_{0.05} \mathrm{O}_{2}, 210 \mathrm{mAh} \mathrm{g}{ }^{-1}\right)$, kinetic limitations in the anode lead to a lowered voltage plateau compared to NCM half-cells. The solid electrolyte $\left(\mathrm{Li}_{6} \mathrm{PS}_{5} \mathrm{Cl}, 3 \mathrm{mS} \mathrm{cm}^{-1}\right)$ does not penetrate the $\mathrm{Si}-\mathrm{C}$ void structure resulting in less side reactions and higher initial coulombic efficiency compared to a liquid electrolyte $(72.7 \%$ vs. $31.0 \%)$. Investigating the influence of balancing of full cells using 3-electrode ASSB cells revealed a higher delithiation of the cathode as a result of the higher cut-off voltage of the anode at high $\mathrm{n} / \mathrm{p}$ ratios. During galvanostatic cycling, full cells with either a low or rather high overbalancing of the anode showed the highest capacity retention of up to $87.7 \%$ after 50 cycles.
\end{abstract}

\section{Introduction}

Global warming, limited availability of fossil fuels as well as the exposition to health-damaging air pollutants arising from road traffic especially in cities require new mobility concepts. Electric vehicles (EV) with batteries as energy storage are a promising alternative to internal combustion engine vehicles. ${ }^{[1,2-4]}$ Lithium ion batteries (LIBs), the dominating technology used in portable electronics, are ideally suited for EV due to their high energy and power density. ${ }^{[2,3,5]}$ However, the energy density of the intercalation-based state-of-the-art LIB with a layered oxide as cathode and graphite as anode is limited. ${ }^{[6,7]}$

High-performance anode materials are required to further increase the driving range and shorten the charge times of EV. ${ }^{[6,8,9]}$ Furthermore, the volatile and flammable liquid electrolytes (LEs) used in conventional LIBs pose safety concerns All-solid-state batteries (ASSBs) using solid electrolytes (SEs) instead of organic solvents can potentially provide safer LIBs. ${ }^{[10]}$ In addition, the mechanical rigidity of SEs may prevent the growth of lithium dendrites and thus enable the use of lithium metal as anode material. ${ }^{[11]}$ The gravimetric and volumetric capacity of lithium $\left(3860 \mathrm{mAh} \mathrm{g}^{-1}, 2050 \mathrm{mAh} \mathrm{cm}^{-3}\right)^{[12]}$ is significantly higher than the theoretical capacity of graphite (339 mAh g-1, $\left.747 \mathrm{mAh} \mathrm{cm}^{-3}\right)^{[12]}$ leading to a theoretical increase in energy density of up to $70 \% .{ }^{[11]}$ However, remaining problems like high reactivity of lithium metal, volume expansion during cycling and thermodynamic instability of most electrolytes against lithium metal need to be further addressed..$^{[7,11]}$ Additionally, formation of lithium dendrites even through glass ceramic solid electrolytes along the grain boundaries can also take place in ASSBs leading to short circuits ${ }^{[13]}$ and contact loss at the anode/SE interface under high anodic load due to vacancy diffusion limitation induced pore formation. ${ }^{[14]} \mathrm{Ag}-\mathrm{C}$ nanocomposite framework layers as anode could be a promising approach to both suppress Li dendrite formation and obtain high energy densities and long cycle life. ${ }^{15]}$ The lithium alloy forming element silicon is another attractive alternative to lithium due to its high gravimetric and volumetric capacity (1857 $\left.\mathrm{mAh} \mathrm{g}^{-1}, 2190 \mathrm{mAh} \mathrm{cm}^{-3}\right)$, low delithiation potential $\left(0.4 \mathrm{~V}\right.$ vs. $\left.\mathrm{Li}^{\prime} / \mathrm{Li}^{+}\right)$and high abundance lowering battery production costs. ${ }^{[12,16,17,18]}$ Tesla just recently announced that their future battery technology will be based on cheap and abundant silicon anodes. ${ }^{[19]}$ However, bulk silicon cannot be effectively utilized in a battery. The high volume change of silicon during (de)lithiation of about $300 \%$ lead to particle pulverization, loss of electrical contact and an instable solid electrolyte interphase (SEI), resulting in low coulomb efficiency and permanent capacity decay. ${ }^{[4,18,20]}$ In order to compensate the volume changes of silicon, several nano-scaled materials such as silicon nanoparticles ${ }^{[21,22]}$, nanowires ${ }^{[23,24]}$, nanotubes ${ }^{[25]}$, and thin films ${ }^{[26,27]}$ have been developed. It has been shown that crystalline silicon nanoparticles with a diameter $<150 \mathrm{~nm}$ do not crack $^{[21]}$ although $\mu \mathrm{m}$-scaled columnar silicon structures ${ }^{[27,28]}$ are a viable anode system. To further improve the mechanical stability and the conductivity of the silicon anode, several composites of the silicon nanostructures with carbon ${ }^{[18,29]}$, transition metal oxides like $\mathrm{TiO}_{2}{ }^{[30]}$, metals ${ }^{[31]}$, and polymers ${ }^{[32]}$ have been designed. However, these composites have mostly been analyzed as anode material in conventional LIBs with liquid electrolytes yet. 
Although encouraging results of nano-scaled silicon anodes with liquid electrolytes regarding capacity, initial coulombic efficiency (ICE), rate capability and capacity retention have been published ${ }^{[18,33]}$, safety issues and also higher costs due to the need of electrolyte additives ${ }^{[34]}$ and special separators ${ }^{[11,35]}$ are still present in conventional lithium ion batteries.

Replacing the liquid electrolyte with a SE improves the thermal stability ${ }^{[1]}$ and partially prevents electrolyte depletion as only lithium ions are mobile ${ }^{[11,36,37]}$ in the battery cell. Regarding the volume changes of silicon during cycling, the solid-state approach also hinders the permanent formation and growth of the SEI in ASSBs compared to conventional LIBs. ${ }^{[28,37]}$ In our previous work, we showed that columnar silicon anodes form a stable 2D SEI when in contact with sulfide solid electrolyte which reduces the surface area for side reactions, prevents depletion of the liquid electrolyte that penetrates into even smallest pores of the active material and eventually leads to higher ICE and capacity retention. ${ }^{[28]}$

Other studies analyzing silicon as potential high-energy anode for ASSBs in the form of amorphous silicon films ${ }^{[37,38]}$, composite electrodes constituted of porous SiNPS, SE and acetylene black $^{[39]}$ or a particulate anode composed of crystalline silicon nanoparticles prepared by spray deposition ${ }^{[40]}$ show lithiation capacities of up to $3000 \mathrm{mAh} \mathrm{g}^{-1} \mathrm{si}$ with a capacity retention of up to $93 \%$ over 100 cycles and good rate capabilities in half-cells. However, full cell studies taking proper balancing into account are rare.

In order to address the issue of the drastic volume changes of silicon during cycling we investigate silicon carbon void structures (Si-C) in this study as anode material for ASSBs both in half-cells vs. lithium and full cells with nickel-rich layered oxide (NCM) as cathode. $\mathrm{Li}_{6} \mathrm{PS}{ }_{5} \mathrm{Cl}$ - an argyrodite-type sulfide electrolyte - is used as solid electrolyte. Within the different types of SEs, sulfide solid electrolytes (SSEs) like $\mathrm{Li}_{6} \mathrm{PS}_{5} \mathrm{Cl}$ possess ionic conductivities comparable to liquid electrolytes. ${ }^{[41]}$ Furthermore, SSEs can be compressed at room temperature which enables prototype cell manufacturing. ${ }^{[42]}$
Silicon carbon composites have only been rarely analyzed in combination with SEs yet but e.g. nanostructured Si/C fibers in ASSBs deliver a reversible capacity of about $700 \mathrm{mAh} \mathrm{g}^{-1}$ over 70 cycles with CEs up to $99.2 \%$ in half-cells. ${ }^{[43]}$ The nanostructured $\mathrm{Si}-\mathrm{C}$ composites used in this study offering a void between the silicon nanoparticle (SiNP) and the outer carbon shell ${ }^{[12,44]}$ have already been analyzed in conventional LIBs. ${ }^{[18]}$ The free volume between the silicon core and the carbon matrix does not only allow a free volume expansion of silicon but the carbon shell also increases the electric conductivity of the anode and the stability of the SEI which forms at the outer carbon shell surface. ${ }^{[8,12,18,44]}$ To the best of our knowledge, we report here for the first time, nanostructured silicon carbon composite void structures as anodes in all-solid-state Li-ion batteries and their successful implementation into full cells. Similar to liquid electrolytes, the carbon shell can effectively compensate the volume changes of silicon which improves the electrochemical performance compared to bare SiNPs (Figure 1). In contrast to liquid electrolytes, ASSB full cells using the proposed $\mathrm{Si}-\mathrm{C}$ void anodes in combination with $S E s$ require no precycling in half-cell vs. lithium. ${ }^{[18]} \mathrm{A}$ crucial advantage is the SE, which cannot penetrate into the entire void structure of the Si-C composite as it would be the case for a liquid electrolyte, causing repeated SEI formation and detrimental (initial) irreversible lithium loss. The SE in contact with Si-C significantly reduces such classical decay mechanisms (Figure 1). Further benefits of ASSBs are high(er) practical areal loadings of the electrodes and a mechanically stabilized SEI by an external pressure.

Herein, Si-C composites with variable Si mass contents are firstly analyzed in half-cells vs. lithium. Subsequently, the Si-C composite with the most promising electrochemical performance is used as active anode material in full cells vs. NCM. Within the full cells, various $n / p$ ratios ranging from 1.1 to 2.0 are electrochemically studied to investigate the influence of the balancing on the cell performance as well as to find an optimal ratio between anode and cathode capacity. Mechanistic insights are provided using an ASSB-3-electrode setup revealing the evolution of the involved electrodes in NCM|SE|Si-C full cells.

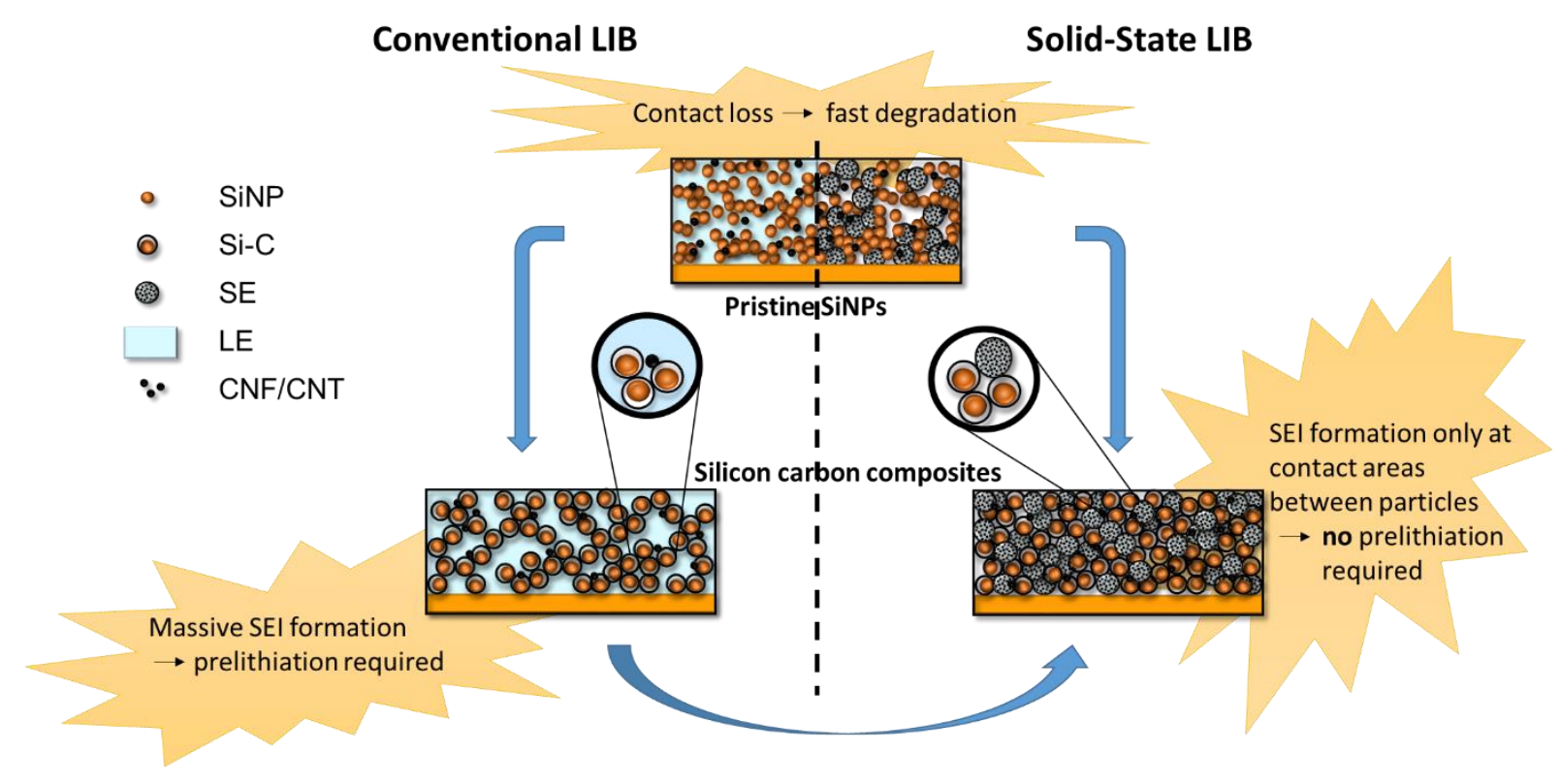

Figure 1. Schematic representation of SiNP (top) and Si-C (bottom) anode in liquid (left) and solid electrolyte (right) Li-ion battery systems. 


\section{Results and Discussion}

\section{Structural characterization of Si-C composites}

Several Si-C composites were synthesized using silicon nanoparticles (SiNPs), polyvinylbutyral (PVB) as void template and sucrose as carbon precursor applying a similar route as previously described. ${ }^{[18,44]}$ After melt coating PVB on the SiNPs, the sucrose is polymerized via a wet-chemical process around the particles. During pyrolysis, PVB is removed through thermal decomposition whereby voids are formed in-situ. As different Si to PVB mass ratios were adjusted at the beginning of the synthesis, the $\mathrm{Si}-\mathrm{C}$ composites contain different mass factions of $\mathrm{Si}$, which were determined by combustion analysis (Table 1). Hence, the Si-C composites (Si28@C, Si34@C, Si37@C) are named after their respective Si content.

Table 1. Starting PVB:Si mass ratio and estimated $\mathrm{Si}$ content of $\mathrm{Si}-\mathrm{C}$ composites.

\begin{tabular}{lll}
\hline Label & PVB:Si mass ratio & Si content (mass fraction \%) \\
\hline Si28@C & $3: 1$ & 28.21 \\
Si34@C & $1: 2$ & 34.45 \\
Si37@C & $5: 1$ & 36.86
\end{tabular}

The X-ray diffraction pattern of the $\mathrm{Si}-\mathrm{C}$ composite with a $\mathrm{Si}$ content of $28.21 \%$ (Si28@C) shows only small peaks originating from a carbon phase ${ }^{[45]}$, but stronger peaks of the cubic facecentered silicon lattice (Figure $2 \mathrm{a}$ ) proving the presence of crystalline SiNPs. ${ }^{[39]}$ The peaks at $295 \mathrm{~cm}^{-1}, 946 \mathrm{~cm}^{-1}$, and the intensive band at $513 \mathrm{~cm}^{-1}$ in the Raman spectra (Figure $2 \mathrm{~b}$ ) origin from crystalline silicon (c-Si). ${ }^{[46,47]}$ While the peak at $513 \mathrm{~cm}^{-1}$ originates from the scattering of the first-order optical phonon of $\mathrm{c}-\mathrm{Si}$, the peaks at $295 \mathrm{~cm}^{-1}$ and $946 \mathrm{~cm}^{-1}$ are due to the scattering of two transverse acoustic and two transverse optical phonons, respectively. ${ }^{[46]}$ The carbon shell surrounding the $c$-SiNPs causes the D- $\left(1348 \mathrm{~cm}^{-1}\right)$ and G-band $\left(1594 \mathrm{~cm}^{-1}\right) \cdot{ }^{[48]}$ The carbon matrix surrounding the SiNPs is also visible in the transmission electron microscopy (TEM) images (Figure 2c-d). In contrast to other core shell templates ${ }^{[44]}$, voids are not clearly visible possibly due to a lower contrast in the TEM images. This indicates an intimate contact between carbon and silicon. Since PVB decomposes during carbonization, a particular porosity is still expected. ${ }^{[18]}$ Similar XRD patterns, Raman peaks and TEM images can also be observed for the Si-C composites Si34@C and Si37@C (Figure S1, Figure S2).

To investigate the morphology of the $\mathrm{Si}-\mathrm{C}$ composites and compare them to bare SiNPs, the materials were analyzed by scanning electron microscopy (SEM). The SEM images of the commercially available SiNPs show globular, partially aggregated nanoparticles (Figure 3a). The aggregation lowers the surface energy of the nanoparticles and leads to a carbon coating of SiNP agglomerates rather than individual SiNPs as can been seen in the SEM images of the Si-C composites (Figure $3 b-d) \cdot{ }^{[44]}$ Although a homogeneous carbon coating surrounding the crystalline SiNPs is observable for all Si-C composites (Figure $3 b-d)$, the structure differs for the respective PVB:Si mass ratio employed in the synthesis and the resulting Si content.
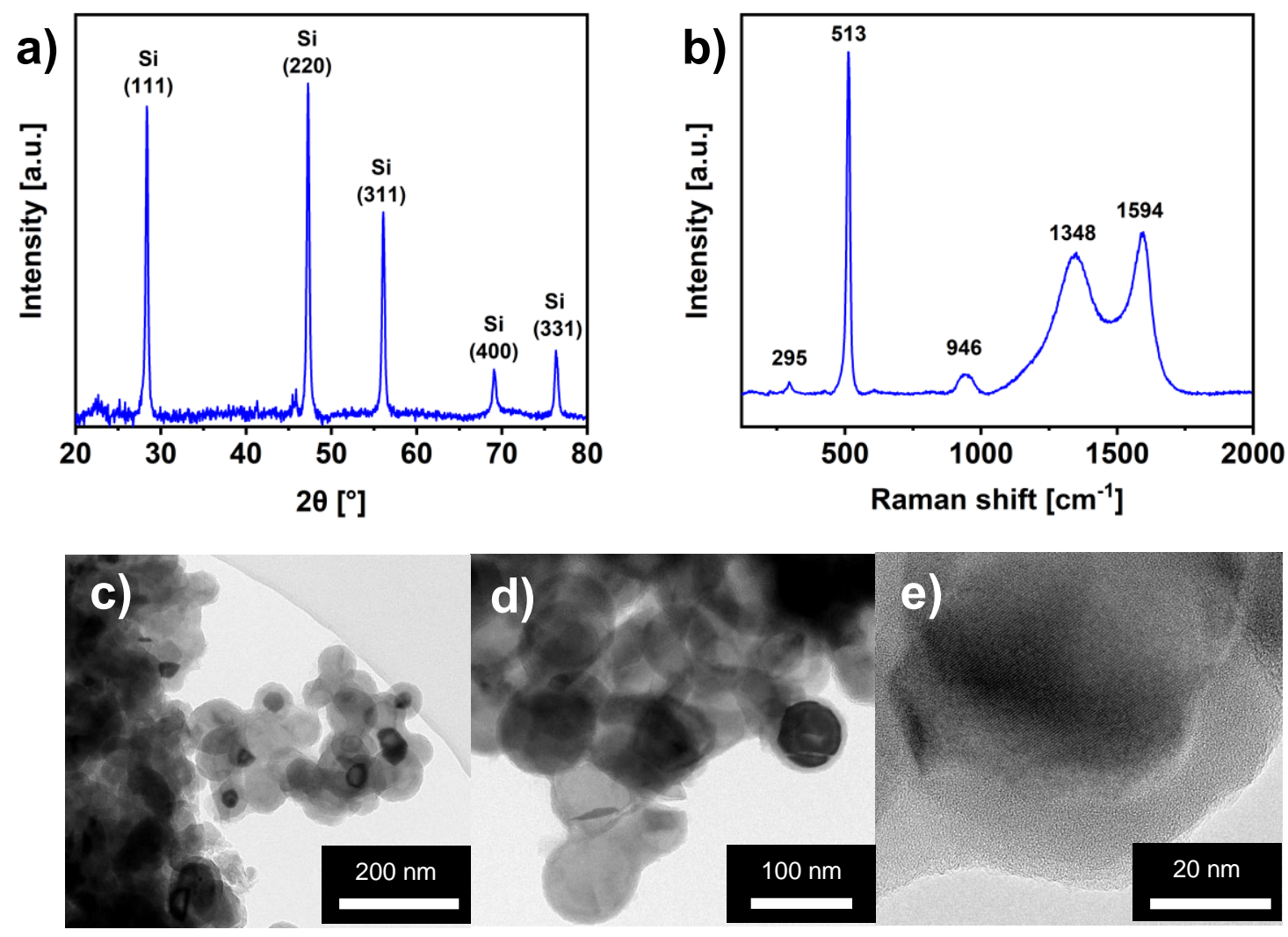

Figure 2. XRD powder pattern (a), Raman spectrum (b) and TEM images (c-e) of the Si-C composite with a Si content of $28 \%$ (Si28@C). 


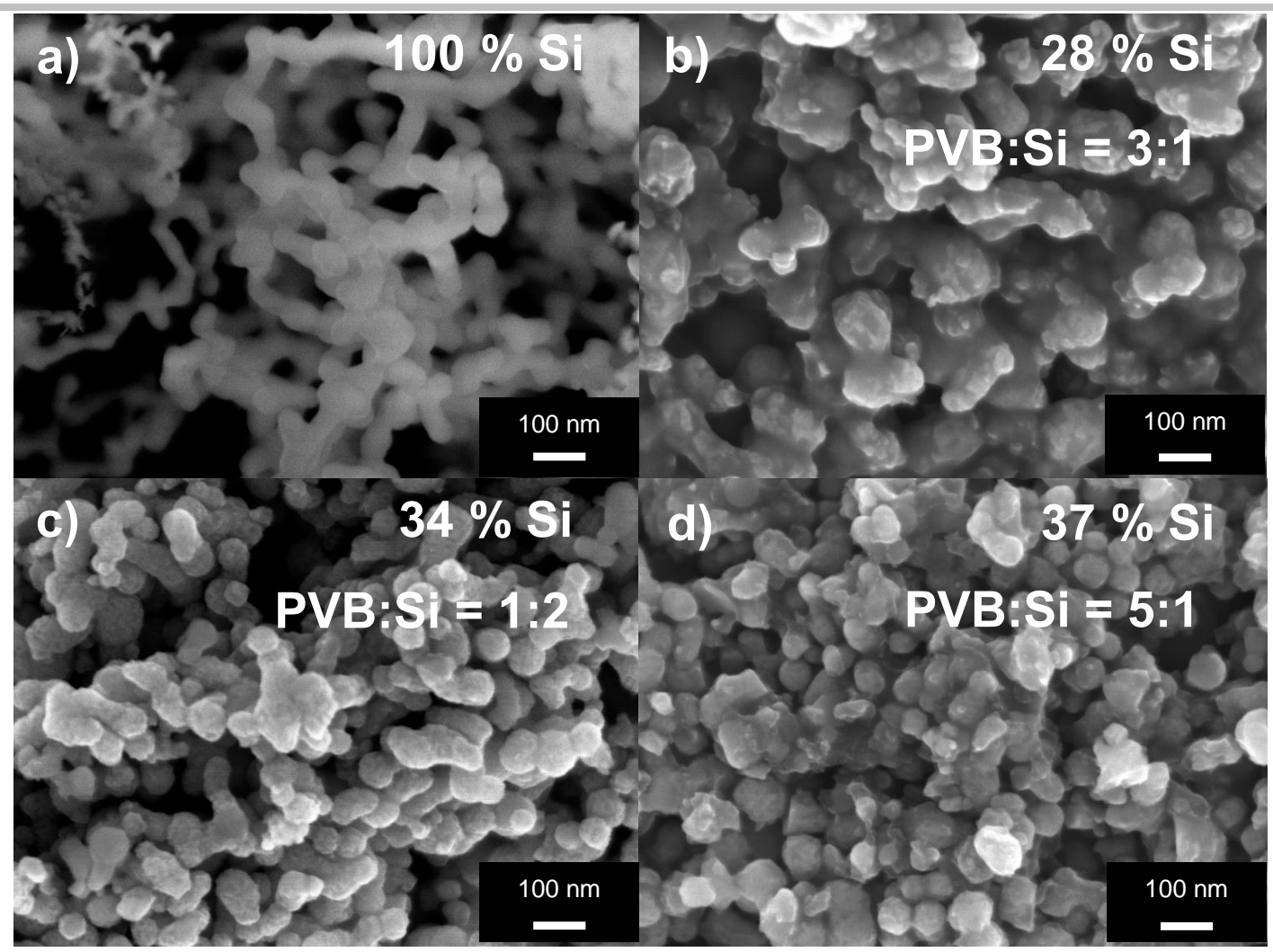

Figure 3. SEM images of bare SiNPs (a) and of the Si-C composites Si28@C (b), Si34@C (c) and Si37@C (d).

The Si-C particles of Si34@C (Figure 3c, $60 \pm 8 \mathrm{~nm}$ ) have almost the same diameter as the bare SiNPs $(52 \pm 5 \mathrm{~nm})$ and are smaller compared to Si37@C (Figure 3d, $64 \pm 7$ nm) or Si28@C (Figure 3b, $94 \pm 16 \mathrm{~nm}$ ) particles, which is due to the smaller amount of the void template in the synthesis of Si34@C. However, the values should not be overestimated as only a certain area of the sample is analyzed. A higher PVB content in the synthesis (3:1, $5: 1)$ leads to a more compact structure of the Si-C composites. In addition, PVB does not only act as void template but also as carbon source, since the PVB:Si mass ratio also influences the C-content of the composites (Table 1).

Compared to the bare SiNPs, the diameter as well as the degree of agglomeration of the embedded SiNPs beneath the carbon shell increases from Si34@C (PVB:Si = 1:2) over Si37@C (PVB:Si = 5:1) to Si28@C (PVB:Si = 3:1) which also leads to the larger diameter of the $\mathrm{Si}-\mathrm{C}$ agglomerates and decreasing interparticle distances of the composites in this order.

\section{Electrochemical characterization of nanostructured Si-C composites in half-cells}

For electrochemical testing, the $\mathrm{Si}-\mathrm{C}$ composite anodes were assembled with Si-C (Si28@C, Si34@C, Si37@C) as active material, $\mathrm{Li}_{6} \mathrm{PS}_{5} \mathrm{Cl}$ as solid electrolyte and $\mathrm{CNF}$ as conductive additive. Bare SiNPs as well as a Si/C65 mixture containing silicon and carbon nanoparticles in the same Si:C mass ratio as Si37@C are used as reference active materials in order to analyze which impact the carbon void structure surrounding the SiNPs in the Si-C has on the cell performance.

Initially, the lithiation and delithiation mechanism of the Si-C composites were investigated by galvanostatic cycling with potential limitation (GCPL) and cyclic voltammetry (CV). The first lithiation (discharging) starts from c-SiNPs. The flatter voltage profile of the Si-C composite electrodes until around $0.4 \mathrm{~V}$ (Figure 4a) as compared to the abrupt descend voltage curve of the bare SiNP electrode (Figure S3a) can be explained with the carbon shell surrounding the SiNPs. The lithium ions have to penetrate the carbon shell, before being able to form a new silicide phase with silicon. The shallow voltage curve is observable in graphite half-cells, too (Figure S4). During the first lithiation, a plateau at around $0.08 \mathrm{~V}$ is formed. In this two-phase region $\mathrm{C}-\mathrm{Si}$ and the formed $\mathrm{a}-\mathrm{Li}_{\mathrm{x}} \mathrm{Si}$ phase coexist. ${ }^{[16,49]}$ At voltages lower than $0.05 \mathrm{~V}$, a spontaneous phase transition to $\mathrm{c}-\mathrm{Li}_{15} \mathrm{Si}_{4}$ takes place. ${ }^{[16,20,50]}$ The short plateau at $0.44 \mathrm{~V}$ during the following delithiation (charging) indicates the conversion from c- $\mathrm{Li}_{15} \mathrm{Si}_{4}$ to a- $\mathrm{Li}_{x} \mathrm{Si}_{.}{ }^{[49,50]}$ Subsequently, a- $\mathrm{Li}_{x} \mathrm{Si}$ is delithiated ${ }^{[51]}$ so that after the first cycle an amorphization of the silicon takes place $^{[20]}$, also confirmed by Raman spectroscopy (Figure S5a). Instead of the sharp peak from c-Si at $520 \mathrm{~cm}^{-1}$ that is observable before cycling, a broader peak at $480 \mathrm{~cm}^{-1}$ originating from amorphous silicon (a-Si) is visible after cycling. ${ }^{[52]}$ Hence, the following cycles start from a-Si and no potential plateau is formed during lithiation.

In the corresponding cyclic voltamogramm (Figure 4b), the small peak at $0.9 \mathrm{~V}(\mathrm{I})$ at the beginning of the first cycle originates from reactions of the SE and/or at the Li/SE interface. ${ }^{[53]}$ During the first lithiation (discharging), the increase of the current density (II) is due to the formation of the Li-Si alloy. ${ }^{[24]}$ The (de)lithiation of the carbon matrix is visible from the peaks at $0.1 \mathrm{~V}$ and $0.14 \mathrm{~V}$ (III) during delithiation (charging) in the CV measurement. These peaks arise from the deintercalation of lithium ions from the graphitic domains of the carbon shell. ${ }^{[54]}$ The peak at $0.465 \mathrm{~V}$ (IV) during delithiation corresponds to the short plateau of the voltage curve (Figure 4a). Therefore, this peak matches with the transition from $\mathrm{c}-\mathrm{Li}_{15} \mathrm{Si}_{4}$ to $\mathrm{a}-\mathrm{Li}_{x} \mathrm{Si}_{.}{ }^{[43,50,55]}$ As mentioned before, beginning 


\section{ARTICLE}

from the second cycle the lithiation starts from a-Si and not from c-Si. Subsequently, the shoulder between $0.32 \mathrm{~V}$ and $0.13 \mathrm{~V}(\mathrm{~V})$ builds firstly during the second lithiation. The peak at $0.31 \mathrm{~V}(\mathrm{VI})$ and the shoulder at $0.55 \mathrm{~V}$ (VII) observable especially during the second and third delithiation can be ascribed to the delithiation of a- $\mathrm{Li}_{x} \mathrm{Si}$ which has not been transformed to $\mathrm{c}-\mathrm{Li}_{15} \mathrm{Si}_{4}$ during lithiation. ${ }^{[38,50,55]}$

The galvanostatic cycle stability of the different $\mathrm{Si}-\mathrm{C}$ composites in half-cells vs. lithium as well as of the reference active materials were investigated by GCPL using a current density of $0.07 \mathrm{~mA} \mathrm{~cm}^{-2}$ for the first three cycles and $0.2 \mathrm{~mA} \mathrm{~cm}^{-2}$ for the following 50 cycles. For comparison of all materials, the received discharge (lithiation) capacities are referred to the mass of silicon (Figure 4c).

Regarding the half-cells with the Si-C composites containing different Si contents, the half-cell with Si37@C shows the highest lithiation capacities referred to the mass of silicon during all cycles $\left(>2570 \mathrm{mAh} \mathrm{g}^{-1} \mathrm{si}\right.$ ). The high utilization of silicon can be primarily explained with the highest Si content of Si37@C compared to Si28@C and Si34@C. This is confirmed by the higher current densities in the cyclic voltammogram of the Si37@C|SE|Li cell (Figure 4b) compared to the Si28@C|SE|Li cell (Figure S5b) which are mainly due to the more intensive Si peaks (IV, VI, VII) and correlate with the higher capacities received with GCPL. The ratio between silicon and carbon content is reflected in the intensities of the CV peaks, too, as the peaks from the carbon shell (III) are less intensive during the CV measurement of the Si37@C half-cell.

Comparing the voltage profiles, the curves increase more slowly from Si28@C (Figure S5c) over Si34@C (Figure S5d) to Si37@C (Figure 4a) electrode during delithiation resulting in increasing capacities in this order. Additionally, the comparison of the lithiation capacities referred to the mass of Si-C composite (active material) shows that the capacities increase with the Si content (Figure S6a). This can be due to increased Si utilization but the (de)lithiation of the carbon matrix also contributes to the received capacities.

As the Si37@C half-cell also exhibits the highest lithiation capacities referred to the mass of $\mathrm{Si}-\mathrm{C}$ composite (> $1000 \mathrm{mAh} \mathrm{g}^{-1} \mathrm{si-c}$ after 53 cycles, Figure S6a), the contacting between SiNPs, CNF and SE particles as well as the size of the voids between SiNPs and carbon matrix (Figure 3d) within the Si37@C electrode seem to be most promising for further evaluation. Additionally, the Si37@C half-cell has the lowest average delithiation (charge) potential resulting in a higher full cell potential and hence higher energy density of the ASSB cells. Besides the lower Si content of Si28@C, the decreased capacity of Si34@C electrode can be explained with the lower diameter of the $\mathrm{Si}-\mathrm{C}$ agglomerates (see Figure $3 \mathrm{c}$ ) leading to a less compact structure, more incomplete contacting between the electrode particles and longer ionic pathways in the solid composite electrode.
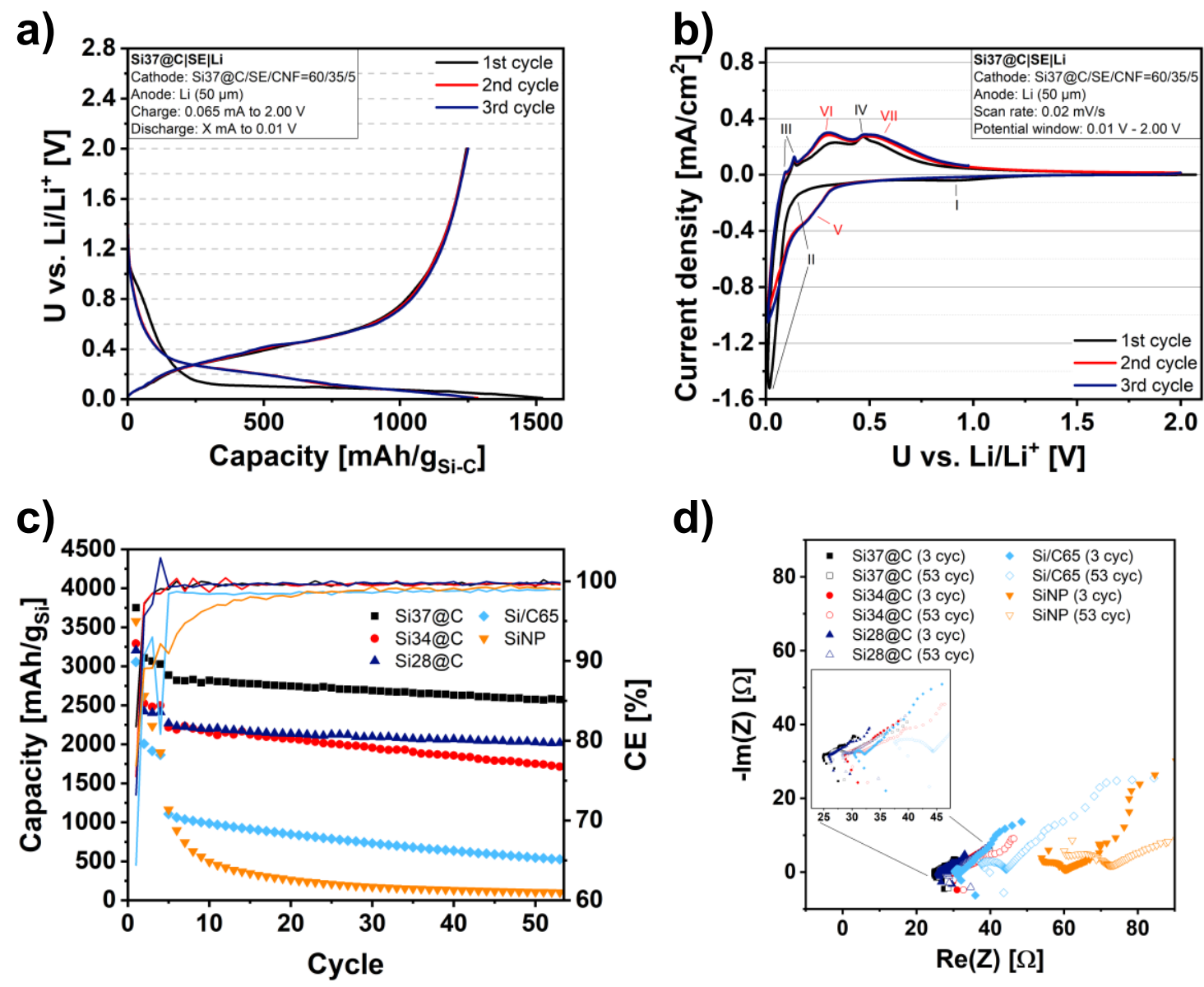

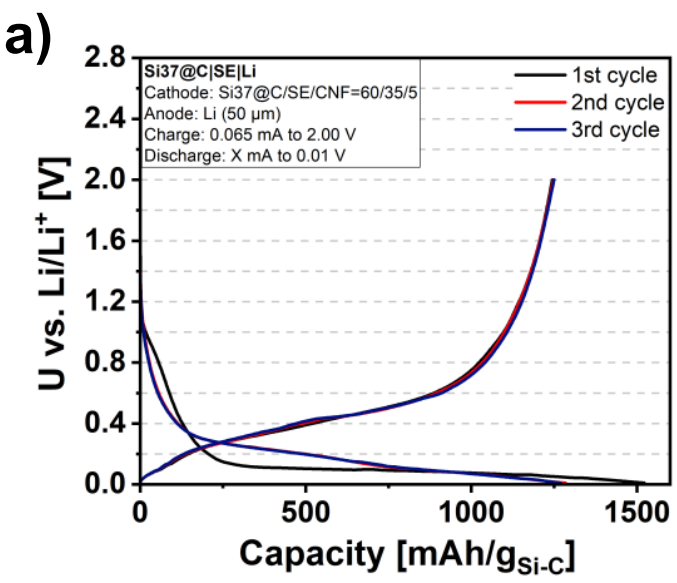

d)

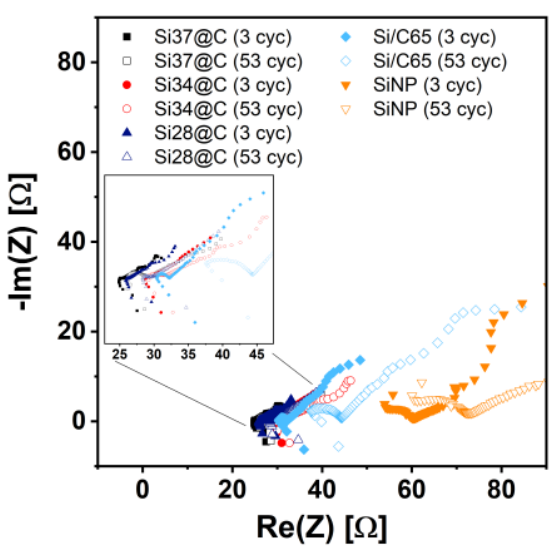

Figure 4. Voltage profiles (a) and cyclic voltammogram (b) of Si37@C|SE|Li half-cell for the first three cycles. Lithiation capacities and coulombic efficencies (CE) of Si-C, Si/C65 and SiNP half-cells vs. lithium (c) and the corresponding EIS spectra (d) after three and 53 cycles. 
The initial CE (ICE) of Si-C half-cells is remarkably higher for the SE cell $(73.2 \%)$ compared to the LE cell $\left(45.3 \%{ }^{[18]}\right)$ due to suppressed SEI formation at the carbon shell. Given to the high applied pressure in the ASSB torque cells, the SEI is also more mechanically stabilized. The liquid electrolyte penetrates the whole carbon matrix whereas the SE is in contact with the Si-C particles solely at the outer surface (Figure 1). This also leads to a significantly lower charge transfer resistance $\left(R_{c t}-\right.$ represented by the diameter of the semicircle) of the SE cell compared to the LE cell, after 3 cycles and especially after 53 cycles (Figure S6b). The comparison of the cycle stability of the Si-C with the Si/C65 and the pristine SiNP solid-state half-cells shows that the lithiation capacities of the reference cells decrease more rapidly. In the $10^{\text {th }}$ cycle, only $495 \mathrm{mAh} \mathrm{g}^{-1} \mathrm{Si}$ and $986 \mathrm{mAh} \mathrm{g}^{-1} \mathrm{si}$ are received for the SiNP and the Si/C65 half-cell, respectively, whereas the lithiation capacities of the Si-C half-cells lie above $2100 \mathrm{mAh} \mathrm{g}^{-1} \mathrm{si}$. The capacity retentions of the $53^{\text {th }}$ cycle referred to the fifth cycle are clearly higher for the Si-C composite electrodes (77\% to $89 \%$ ) than for the reference material electrodes (SiNP: $9 \%$, Si/C65: $48 \%$ ). The high capacity losses of the SiNP and Si/C65 half-cell are due to the structural degradation of the electrode resulting from the volume changes of silicon. ${ }^{[56]}$ Chen et al. ${ }^{[57]}$ showed that early-stage defects during lithiation due to inhomogenities in the SEI cause the mechanical degradation and structural instability of $\mathrm{Si}$ electrodes. The resulting contact losses lead to increased charge transfer resistances in the EIS spectra after 53 cycles compared to the EIS spectra after three cycles (Figure 4d). In contrast, the higher lithiation capacities, the better rate stability and the higher capacity retention of the Si-C half-cells indicate that the volume changes of the SiNPs seem to be well compensated by the carbon shell stabilizing the entire electrode. ${ }^{[8,56]}$ The diameter of the semicircles in the EIS spectra of the Si-C half-cells is lower and does not significantly change after galvanostatic cycling compared to the reference half-cells (Figure 4d). This indicates both a better maintaining of the contacting between active material and SE particles and also a lower SEI formation. In contrast to the SiNP and Si/C65 electrodes, the SEI formation only takes place at the outer surface of the carbon shell of the $\mathrm{Si}-\mathrm{C}$ composites without huge volume changes. ${ }^{[8,56]}$ The carbon shell does not only stabilize the SEI but also increases the electrical conductivity leading to less shifted EIS spectra on the $x$-axis $(\operatorname{Re}(Z)$ axis $) .{ }^{[56]}$ This is already the case when adding carbon nanoparticles in the same mass ratio to SiNPs (Si/C65) as for the best performing Si-C composite Si37@C. However, this mixture is neither capable of buffering the volume changes of the SiNPs nor does the carbon participate in the electrochemistry as can been seen from the voltage profile (Figure S3b) which is similar to the SiNP half-cell. Together with the lower rate and cycle stability of the Si/C65 as well as the SiNP half-cell this proves that the carbon void structure is essential to both compensate volume changes of the SiNPs and improve the electrochemical utilization.

\section{Electrochemical performance of NCM|SE|Si-C full cells}

$\mathrm{NCM}|\mathrm{SE}| \mathrm{Si}-\mathrm{C}$ full-cells with different $\mathrm{n} / \mathrm{p}$ ratios possessing high

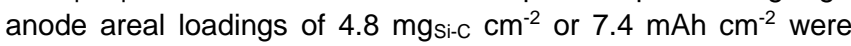
prepared with Si37@C as anode active material and cycled between $1.5 \mathrm{~V}$ and $4.25 \mathrm{~V}$. The good Si-utilization and lithiation of the Si37@C electrode in half-cells vs. lithium makes this composite to the material of choice for use in ASSB full cells. The $\mathrm{NCM}$ cathode active material $\left(\mathrm{LiNi}_{0.9} \mathrm{Co}_{0.05} \mathrm{Mn}_{0.05} \mathrm{O}_{2}\right)$ can achieve a maximum capacity of $207 \mathrm{mAh} \mathrm{g}^{-1} \mathrm{NCM}$, as determined in $\mathrm{NCM}|\mathrm{SE}| \mathrm{Li}$-In half-cell (Figure S7a). In contrast to half-cells supplying an excess of lithium ions through the lithium metal anode, the amount of lithium ions in full cells is limited by the cathode. Thus, lithium ion losses e.g. due to SEI formation directly influence the cell performance. Additionally, the balancing or $n / p$ ratio plays an important role for lithium-ion full cells describing the ratio between the anode and cathode capacity. On the one hand, $\mathrm{n} / \mathrm{p}$ ratios lower than one lead to lithium plating which should be prevented in order to address safety concerns and prolong cycle life. On the other hand, the higher the $n / p$ ratio, the lower the energy density of the cell due to unutilized anode material. ${ }^{[58,59]}$ In order to prevent lithium plating, $n / p$ ratios greater than one are usually employed.

Regarding the rate performance of a full cell with a Si-C anode oversized by $30 \%(n / p=1.3)$, the discharge capacities decrease with increasing discharge current density from $187 \mathrm{mAh} \mathrm{g}^{-1} \mathrm{NCM}$ at $0.07 \mathrm{~mA} \mathrm{~cm}^{-2}$ to $125 \mathrm{mAh} \mathrm{g}^{-1} \mathrm{NCM}$ at $1.47 \mathrm{~mA} \mathrm{~cm}^{-2}$ (Figure 5a). The lithium ions cannot directly (de)alloy in silicon as they also have to cross the carbon shell. Thus, smaller discharge capacities are observable at high current densities resulting from higher kinetic limitations of the lithium ion diffusion particularly in the Si-C anode compared to $\mathrm{NCM}|\mathrm{SE}|$ graphite or $\mathrm{NCM}|\mathrm{SE}| \mathrm{Li}-\mathrm{In}$ reference cells (Figure S7a and b). The first discharge capacity (Figure $5 b$ ) of the $\mathrm{NCM}|\mathrm{SE}| \mathrm{Si}-\mathrm{C}$ cell only achieves about 90 to $92 \%$ of the discharge capacity of a NCM|SE|Li-In or NCM|SE|graphite reference cell, respectively, which can be increased up to 94 or $95 \%$ with an additional constant voltage step (CV step) at the end of discharge (dark blue curve in Figure 5b). Although SEI formation and side reactions are significantly reduced in ASSBs, minor irreversible lithium losses are still present. The lowered average voltage during discharge of the $\mathrm{NCM}|\mathrm{SE}| \mathrm{Si}-\mathrm{C}$ full cell originates from the flatter descend of the corresponding voltage profile especially above $80 \%$ depth of discharge (DOD). The voltage profile of the Si-C half-cell (Figure 4a) near the end of charging is not as steep as of the graphite half-cell (Figure S4) resulting in the flatter voltage curve of the $\mathrm{NCM}|\mathrm{SE}| \mathrm{Si}-\mathrm{C}$ full cell near the end of discharge. However, using the $\mathrm{Si}-\mathrm{C}$ composite as anode material high areal loadings of $7.4 \mathrm{mAh} \mathrm{cm}^{-2}$ were realized and the higher volumetric capacity of the anode display a remarkable benefit for designing high-energy full cells

The slight difference of the discharge capacities between $\mathrm{NCM}|\mathrm{SE}| \mathrm{Si}-\mathrm{C}$ cells with the same balancing (Figure $5 \mathrm{~b}$ ) can be ascribed to the different long discharge plateau due to the manual fabrication of the ASSB cells. The resulting various local loadings of the anode can lead to differences in the local $C$ rate as well as in the rate and cycle stability of full cells with the same $n / p$ ratio due to various kinetic limitations.

In order to investigate the influence of the balancing on the full cell performance, $\mathrm{NCM}|\mathrm{SE}| \mathrm{Si}-\mathrm{C}$ cells with different $n / p$ ratios were prepared. At first, the anode and cathode potential curves of a cell with a low (1.3) and a high (2.0) $\mathrm{n} / \mathrm{p}$ ratio was studied with a 3-electrode ASSB setup using lithium as reference electrode since the typical 2-electrode setup only allows measuring the full cell potential. The full cells were fabricated with a constant anode capacity resulting in decreasing cathode capacity with increasing $\mathrm{n} / \mathrm{p}$ ratio and explaining the difference in areal capacity between low and high overbalancing of the anode (Figure $5 \mathrm{c}, 5 \mathrm{~d}$ ). After charging (lithiation of the anode) both cells with a current density of $0.07 \mathrm{~mA} \mathrm{~cm}^{-2}$ until $4.25 \mathrm{~V}$ (Figure $5 \mathrm{c}$ ), the anode voltage of the cell with an $n / p$ ratio of $2.0(0.077 \mathrm{~V})$ lies above the anode potential 


\section{a)}

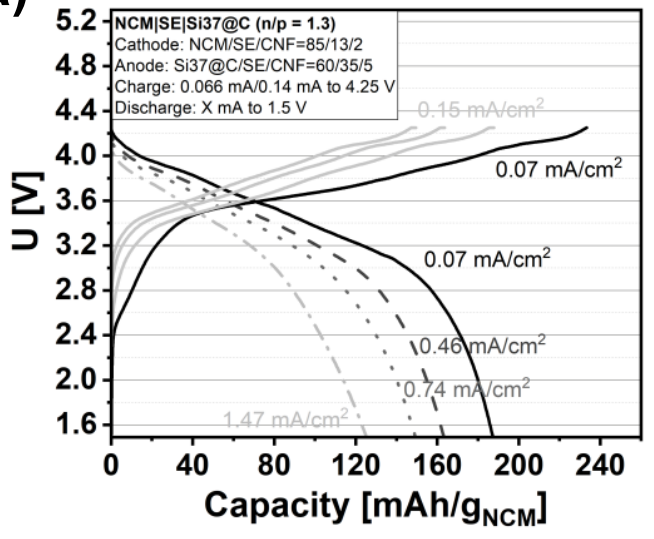

c)

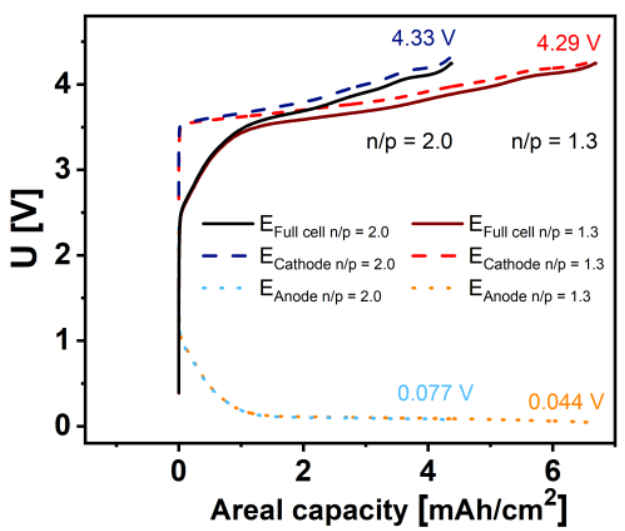

b)

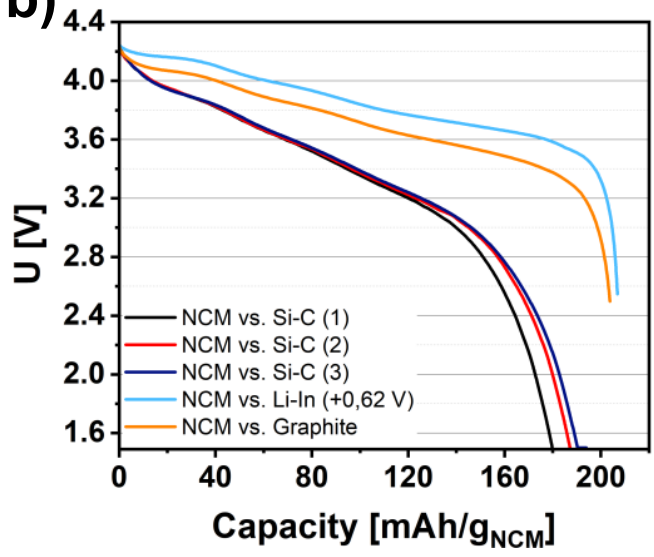

d)

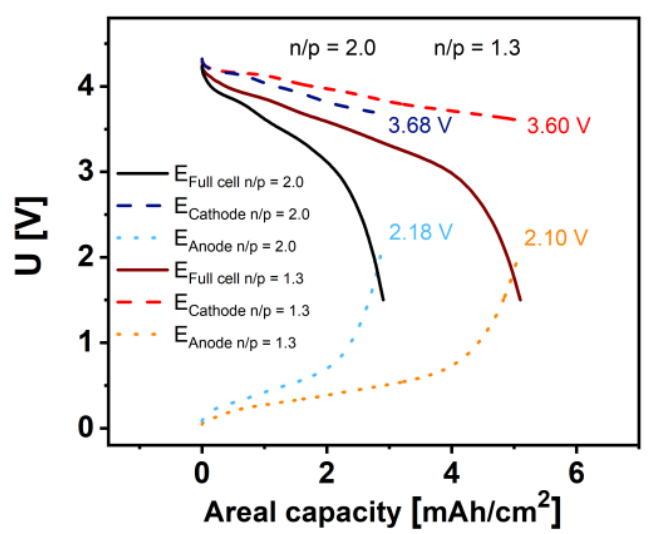

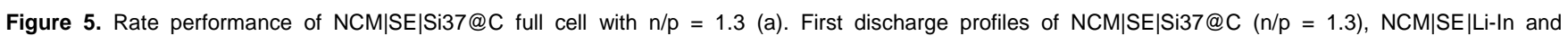
$\mathrm{NCM}|\mathrm{SE}|$ graphite $(\mathrm{n} / \mathrm{p}=1.8)$ cells with a current density of $0.07 \mathrm{~mA} \mathrm{~cm}^{-2}(\mathrm{~b})$. First charge $(\mathrm{c})$ and discharge profiles (d) of 3-electrode NCM|SE|Si37@C full cells with $n / p=1.3$ and $n / p=2.0$ using lithium as reference electrode $\left(0.07 \mathrm{~mA} \mathrm{~cm}^{-2}\right)$.

of the cell with an $n / p$ ratio of $1.3(0.044 \mathrm{~V})$. The reason for this is the lower utilization and lithiation of the anode with increasing overbalancing of the anode (higher $n / p$ ratio). ${ }^{[58]}$ For reaching the predefined charge cut-off voltage of the full cell $(4.25 \mathrm{~V})$, the cathode potential at the end of charge is higher for the $\mathrm{n} / \mathrm{p}$ ratio of $2.0(4.33 \mathrm{~V})$ than for the $\mathrm{n} / \mathrm{p}$ ratio of $1.3(4.29 \mathrm{~V}) .{ }^{60]}$ This leads to a higher delithiation of the cathode of the cell with an $n / p$ ratio of 2.0 which goes along with enhanced structural instability of the cathode. ${ }^{[58,61]}$ After discharging (lithiation of the cathode) the cells until $1.5 \mathrm{~V}$ (Figure $5 \mathrm{~d}$ ), the end potentials of anode and cathode are again higher for the cell with an $n / p$ ratio of 2.0 than for the cell with an $n / p$ ratio of 1.3 . The steep increase of the anode potential curve near the end of discharge, observable for both cells, indicate the full delithiation of the Si-C anode. However, the cathodes are not fully lithiated yet at the end of discharge since the end of discharge potential of the cathodes only lies around 3.6 V. ${ }^{[62]}$ This can be explained with the SEI formation and the corresponding irreversible loss of lithium ions whereby not all lithium ion sites in the NCM lattice can be filled again. ${ }^{[59]}$ Summarizing, a higher oversizing of the anode (higher $\mathrm{n} / \mathrm{p}$ ratio) leads to less mechanical stress for the anode but at the same time to higher strain for the cathode. Similar results between low and high overbalancing of the anode were obtained by investigating NCM|LE|Si cells. ${ }^{[59]}$
Regarding the rate performance and galvanostatic cycle stability of the NCM $|\mathrm{SE}| \mathrm{Si}-\mathrm{C}$ cells with different $\mathrm{n} / \mathrm{p}$ ratios, the trends within the first charge capacities and initial coulombic efficiencies (ICE) are considered firstly (Figure 6a). In common with NCM|LE|S cells ${ }^{[59]}$, the first charge capacity of NCM|SE|Si-C cells increases and the corresponding ICE decreases with rising $n / p$ ratio. The increasing end of charge potentials of the cathode at higher overbalancing of the anode and the corresponding higher amount of extracted lithium ions from the cathode lead to the increasing charge capacities. However, as mentioned before, the stronger delithiation also leads to increased structural instability of the cathode. Subsequently, it comes to aggravated and incomplete lithiation of the cathode during discharge, the capacity losses increase and the ICE decreases. ${ }^{[58,61,63]}$

Another factor contributing to the decreasing ICE are the dropping cathode capacities - and consequently the amount of available lithium ions in the full cell - with rising $n / p$ ratio. As the same amount of lithium ions is consumed through the SEl formation at the anode for all full cells (by assuming constant anode capacity), the relative capacity loss increases with rising overbalancing of the anode whereby the ICE sinks. This also explains the higher end of discharge potential of the cathode of the full cell with an $\mathrm{n} / \mathrm{p}$ ratio of 2.0 (3-electrode setup, Figure $5 \mathrm{~d}$ ) as less lithium ions are available to intercalate into the NCM lattice. ${ }^{[59]}$ 
a)

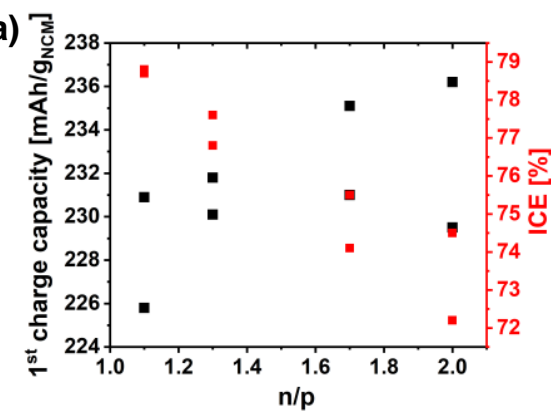

b)

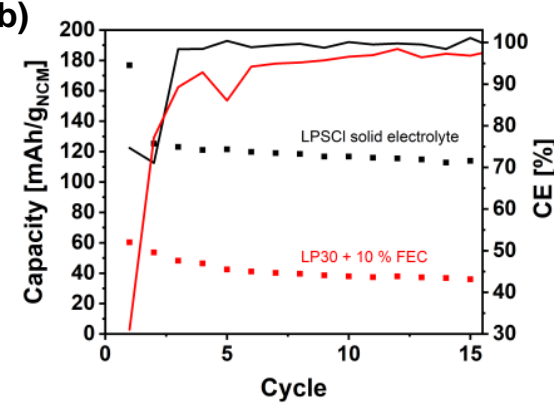

c)

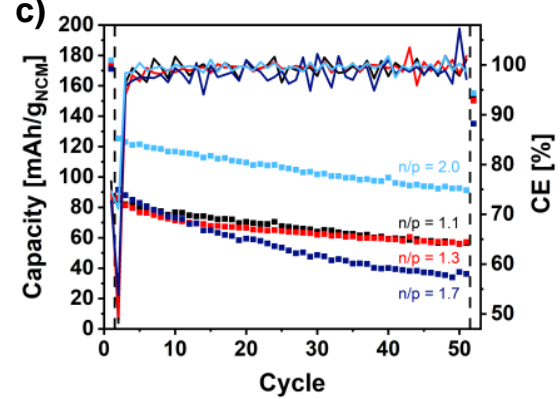

Figure 6. First charge capacities and initial coulombic efficiencies (ICE) of NCM|SE|Si37@C full cells dependent on the n/p ratio (a). Cycle performance of full cells $(\mathrm{n} / \mathrm{p}=2.0)$ with liquid and solid electrolyte composed of NCM as cathode and Si-C as anode (b). Discharge capacities and CE of NCM|SE|Si37@C full cells with different $n / p$ ratios $(c)$.

Although the investigation of the rate performance (of 4 cycles) of the $\mathrm{NCM}|\mathrm{SE}| \mathrm{Si}-\mathrm{C}$ full cells with different $\mathrm{n} / \mathrm{p}$ ratios barely reveal differences (Figure S8), more notable trends and differences between various $n / p$ ratios are recognizable through monitoring the galvanostatic cycle stability (Figure $6 c$ ).

A clear difference is visible regarding the electrochemical performance of $\mathrm{NCM}|\mathrm{SE}| \mathrm{Si}-\mathrm{C}$ and $\mathrm{NCM}|\mathrm{LE}| \mathrm{Si}-\mathrm{C}$ full cells (Figure $6 b$ ) with the same $n / p$ ratio (note that a different NCM was used in the liquid system to achieve a comparable areal loading in both systems). While the LE cell possess a lower average CE (around $94.7 \%$ ) due to more continuous SEI formation at the anode, the SE cell delivers a higher average CE (around $99.4 \%$ ). In addition, the capacity of the SE cell in the $10^{\text {th }}$ cycle $\left(117 \mathrm{mAh} \mathrm{g}^{-1} \mathrm{NCM}\right)$ is three times as high as the capacity of the LE cell ( $\left.38 \mathrm{mAh}^{-1} \mathrm{NCM}\right)$. Besides the mechanically stabilized SEI by external pressure in the SE cell, the differences can be mainly explained as following. The solid electrolyte does not penetrate the whole void structure of the Si-C composite in contrast to the liquid electrolyte leading to less electrolyte depletion in the inner parts of the Si-C composite. This also results in a significantly higher ICE of the solid system $(72.7 \%)$ than for the liquid system (31.0\%) since the reduced surface area for SEI formation leads to a lower loss of lithium ions during the first cycle. As a result, NCM|LE|Si-C cells have to be precycled or prelithiated in order to compensate the high initial capacity losse ${ }^{[18]}$, which is not necessary for NCM|SE|Si-C cells.

During galvanostatic cycling of the ASSB cells with different $n / p$ ratios, fresh cells were cycled with a low current of $0.07 \mathrm{~mA} \mathrm{~cm}^{-2}$ for charge and discharge of the first (formation) and the last cycle to determine the capacity retention. The cycle stability of the cells was investigated for 50 cycles using $0.2 \mathrm{~mA} \mathrm{~cm}^{-2}$ and $1.0 \mathrm{~mA} \mathrm{~cm}^{-2}$ during charge and discharge, respectively (Figure $6 \mathrm{c}$ ). Over the 50 cycles, the decreasing discharge capacities (rate performance loss) arise from increasing charge transfer resistances (Figure S9) and the corresponding rising overpotentials. In the last cycle with a low current density as in the first cycle, all cells achieve almost the initial capacity proving the high reversibility of NCM|SE|Si-C cells (Table 2, $78.9 \%-87.7 \%$ ). The difference between the capacity of the first (formation) and the last cycle reflects the capacity loss due to irreversible lithium ion losses. The Si-C anode provides higher capacity retentions without the occurrence of short circuits compared to lithium as another highenergy anode leading to improved safety and enhanced electrochemical performance under ambient conditions. ${ }^{[28]}$

Throughout the investigation of the cycle stability of the $\mathrm{NCM}|\mathrm{SE}| \mathrm{Si}-\mathrm{C}$ cells over 50 cycles, the cell with an $\mathrm{n} / \mathrm{p}$ ratio of 1.7 shows the highest overpotential increase as can be seen from the rate performance loss (Table 2, 60.4\%) whereas the full cells with a smaller $\mathrm{n} / \mathrm{p}$ ratio (1.1 and 1.3) show a better performance at higher current rates (Table 2, rate performance loss $33.7 \%$ ). This devolution of the discharge capacities can be explained with the difference in the end of charge voltage of the cathode. The higher cathode potential of the cell with an $n / p$ ratio of 1.7 leads to faster degradation of the cathode and thus quicker decreasing of the discharge capacities. ${ }^{[58,63]}$ In contrast, the lower cathode potential of the full cells with smaller overbalancing of the anode $(\mathrm{n} / \mathrm{p}$ ratio of 1.1 and 1.3) improves the galvanostatic cycle performance. However, the full cell with an $n / p$ ratio of 2.0 deviates from the other cells and shows the highest discharge capacities (125 $\mathrm{mAh} \mathrm{g}^{-1} \mathrm{NCM}$ in the $2^{\text {nd }} \mathrm{cycle}$ ) with the lowest rate performance loss within the 50 cycles (Table 2, 27.1\%) as well as the highest capacity retention (Table 2, $87.7 \%$ ). The partial lithiation of the $\mathrm{Si}-\mathrm{C}$ anode at an $\mathrm{n} / \mathrm{p}$ ratio of 2.0 improves its stability during cycling leading to the high cycle stability of this cell despite the higher cathode potential. ${ }^{[18]}$ Furthermore, the different behavior of the cell with an $n / p$ ratio of 2.0 compared to the other cells can be explained with the kinetic limitations of the lithium ion diffusion especially in the Si-C anode influencing the cell performance mainly at high current rates.

Table 2. Galvanostatic cycle performance (capacity loss between cycle 2 and cycle 51, rate performance loss) and reversibility (capacity retention of cycle 52 vs. cycle 1 ) of $\mathrm{NCM}|\mathrm{SE}| \mathrm{Si}-\mathrm{C}$ full cells with different $\mathrm{n} / \mathrm{p}$ ratios.

\begin{tabular}{lllll}
\hline $\mathrm{n} / \mathrm{p}$ & 1.1 & 1.3 & 1.7 & 2.0 \\
\hline $\begin{array}{l}\text { Rate } \\
\text { performance }\end{array}$ & $33.6 \%$ & $33.8 \%$ & $60.4 \%$ & $27.1 \%$ \\
$\begin{array}{l}\text { loss } \\
\text { (between } \\
\text { cycle 2 and } \\
\text { cycle 51) }\end{array}$ & & & & \\
$\begin{array}{l}\text { Capacity } \\
\text { retention } \\
\text { (cycle 1 vs. } \\
\text { cycle 52) }\end{array}$ & $86.8 \%$ & $86.0 \%$ & $78.9 \%$ & $87.7 \%$ \\
\hline
\end{tabular}

Summarizing, full cells with a slight (1.1 or 1.3) or a high (2.0) $n / p$ ratio show the best galvanostatic cycling performance regarding discharge capacities and capacity retention whereas the full cell with an $\mathrm{n} / \mathrm{p}$ ratio of 1.7 shows the highest capacity loss. In addition, estimations of projected energy densities for a unit cell of the cell stack of a multilayered pouch cell (details see supportings) were 
carried out and compared for two $\mathrm{n} / \mathrm{p}$ ratios. The higher utilization of the anode at a lower $n / p$ ratio leads to higher projected energy densities $\left(\mathrm{n} / \mathrm{p}=1.1: 375 \mathrm{Wh} \mathrm{kg}^{-1}, 1178 \mathrm{Wh} \mathrm{l}^{-1}\right)$ compared to full cells with a larger $n / p$ ratio $\left(n / p=2.0: 297 \mathrm{Wh} \mathrm{kg}^{-1}, 874 \mathrm{Wh} \mathrm{l}^{-1}\right)$. Thus, an $\mathrm{n} / \mathrm{p}$ ratio near one is favorable with regard to achievable energy densities.

\section{Conclusion}

Silicon carbon void structures were demonstrated to be excellent performing anode materials in all-solid-state Li-ion batteries. Outstanding cycling performance in solid-state half- and full cells was demonstrated. A close contact between carbon shell and silicon nanoparticle enables the lithiation and stable cycling of the silicon material. This concept leads to higher charging rates at room temperature without short circuits compared to lithium metal anodes. High areal loadings of up to $7.4 \mathrm{mAh} \mathrm{cm}^{-2}$ can be reached. The solid-solid interface reduces the active contact area for side reactions and effectively eliminates continuous SEI formation. In addition, the SEI is mechanically stabilized by external pressure. The result is higher capacity retention and ICE compared to liquid electrolyte systems.

Half-cell measurements vs. lithium demonstrated that the volume changes of the SiNPs are compensated through the carbon matrix since all investigated $\mathrm{Si}-\mathrm{C}$ composites showed higher lithiation capacities, better rate and cycle performance (capacity retention of $77 \%$ to $89 \%$ ) as well as lower cell impedance than the pristine SiNPs (capacity retention of $9 \%$ ) or SiNPs mixed with carbon nanoparticles (Si/C65, capacity retention of $48 \%$ ). The composite with the highest $\mathrm{Si}$ content of $37 \%$ showed the best electrochemical performance (> $1000 \mathrm{mAh} \mathrm{g}^{-1}$ si-c after 53 cycles). In contrast to liquid electrolyte full cells, the solid-state cells comprising $\mathrm{Si}-\mathrm{C}$ void structure composites do not require precycling or prelithiation due to their high initial CE. As the SE is not able to penetrate the $\mathrm{Si}-\mathrm{C}$ void structure like a liquid electrolyte less lithium ions are consumed through SEI formation leading to significantly higher initial discharge capacities and columbic efficiencies compared to the liquid system.

Kinetic limitations in the Si-C composite anode lead to lower discharge capacities of NCM|SE|Si-C full cells at higher current rates. However, decent capacity retention after 50 cycles even at high anode areal loadings as high as $7.4 \mathrm{mAh} \mathrm{cm}^{-2}$ were demonstrated.

Using a 3-electrode ASSB cell setup it was shown that a higher $\mathrm{n} / \mathrm{p}$ ratio of $\mathrm{NCM}|\mathrm{SE}| \mathrm{Si}-\mathrm{C}$ full cells leads to stronger delithiation of the cathode as a result of the higher cut-off voltage (lower utilization) of the anode. The investigation of the balancing of $\mathrm{NCM}|\mathrm{SE}| \mathrm{Si}-\mathrm{C}$ cells showed that full cells either with a low (1.1 or 1.3) or high (2.0) $n / p$ ratio showed the best electrochemical performance. Regarding the energy density, a lower overbalancing of the anode would be favorable. This report is an important study for balancing of novel anode materials against nickel rich cathodes in all-solid-state batteries. With regard to the increasing demand for high-energy batteries, the herein used silicon carbon void structures present a promising concept for both stabilizing anodes and providing high capacities in ASSBs, which is applicable to any future anode materials suffering from high volume changes.

\section{Experimental Section}

\section{Material preparation}

For the synthesis of the silicon carbon composites ${ }^{[18]}, 1.0 \mathrm{~g}$ SiNPs (Alfa Aesar, $98 \%$, APS $\geq 50 \mathrm{~nm}$ ) were mixed with Polyvinylbutyral (PVB, $\mathrm{B} 60 \mathrm{HH}$, Mowital) depending on the PVB:Si ratio $(m: m 1: 2,3: 1,5: 1)$ using a ball mill (MM400, Retsch) for 5 min. Subsequently, the blends were heated at $190{ }^{\circ} \mathrm{C}$ for $30 \mathrm{~min}$. The obtained Si@PVB composite was ground with the ball mill for $5 \mathrm{~min} .2 .66 \mathrm{~g}$ of the ground composite was suspended in $12 \mathrm{ml}$ deionized water and $1 \mathrm{ml}$ ethanol. Subsequently, $3.83 \mathrm{~g}$ sucrose (Sigma Aldrich) and $0.27 \mathrm{~g}$ of a $2.5 \mathrm{M}$ sodium hydroxide (Carl Roth) solution were added under stirring. The mixture was heated for $3 \mathrm{~h}$ at $100{ }^{\circ} \mathrm{C}$ and $6 \mathrm{~h}$ at $160{ }^{\circ} \mathrm{C}$. The ground compound was heated under argon flow with $10 \mathrm{~K} \mathrm{~min}^{-1}$ to $850^{\circ} \mathrm{C}$ and kept for $2 \mathrm{~h}$. After cooling to $50^{\circ} \mathrm{C}$, the obtained Si-C composite was ground again by ball mill. For the Si/C65 mixture, the SiNPs were manually mixed with carbon nanoparticles (C-NERGYTM SUPER C65) using an agate mortar.

The cathode active material, $\mathrm{Li}_{2} \mathrm{O}-\mathrm{ZrO}_{2}(\mathrm{LZO})$ coated $\mathrm{LiNi} 0.9 \mathrm{Co}_{0.05} \mathrm{Mn}_{0.05} \mathrm{O}_{2}$, was prepared by the sol-gel method based on $\mathrm{ZrO}_{2}$ coating. ${ }^{[64]}$ The $\mathrm{LZO}$ coating sol was synthesized from 2-propanol, lithium methoxide (equivalent of $10 \mathrm{wt} \%$-lithium methoxide in methanol solution) and zirconium (IV) tetrapropoxide $\left(\mathrm{Zr}\left(\mathrm{OC}_{3} \mathrm{H}_{7}\right)_{4}\right)$ in the molar ratio 200:2:1. NCM $\left(\mathrm{LiNi}_{0.9} \mathrm{Co}_{0.05} \mathrm{Mn}_{0.05} \mathrm{O}_{2}\right)$ was dispersed in this solution and stirred for $1 \mathrm{~h}$. The 2-propanol was evaporated under vacuum at $50{ }^{\circ} \mathrm{C}$ (water bath) while undergoing ultrasonic treatment in order to avoid aggregation of NCM particles. After filtration, the precursor was heated at $350{ }^{\circ} \mathrm{C}$ for $1 \mathrm{~h}$ under air, and the LZO coated NCM was obtained. The crystal structure of NCM did not change even after the coating procedure and was found to be a-NaFeO2 with $R \overline{3 m}$ space group. A uniform, (X-Ray) amorphous LZO coating with a thickness of $\sim 3.8 \mathrm{~nm}$ has formed (see supportings in Cangaz et al. ${ }^{[28]}$.

The solid crystalline electrolyte $\mathrm{Li}_{6} \mathrm{PS}_{5} \mathrm{Cl}$ was prepared by mechanical milling with high purity (see supportings in Cangaz et al. ${ }^{[28]}$ ) in accordance to the previous publications. ${ }^{[65]}$ Determined amounts of $\mathrm{Li}_{2} \mathrm{~S}$ (Alfa Aesar, 99\%), $\mathrm{LiCl}$ (Alfa Aesar, 99\%) and $\mathrm{P}_{2} \mathrm{~S}_{5}$ (Sigma-Aldrich Co., 99\%) were weighed and mixed in an agate mortar for about $20 \mathrm{~min}$, then transferred in a zirconia $(\mathrm{Zr})$ bowl with $\mathrm{Zr}$ spheres $(10 \mathrm{~mm} \varphi)$ and sealed in an argon filled box. High-energy ball milling was conducted by using the planetary mill P5 (Fritsch, Germany) for $16.5 \mathrm{~h}$ with a rotational velocity of $380 \mathrm{rpm}$. After the milling, the mixture powder was wrapped in a gold foil and placed in a carbon crucible. The carbon crucible was put into a quartz tube and the tube was then vacuum sealed. Using a muffle furnace, the quartz tube was heated at $550{ }^{\circ} \mathrm{C}$ for $1 \mathrm{~h}$. After the heat treatment, the quartz tube was cooled down to room temperature. ${ }^{[28]}$

\section{Electrode preparation}

The powdered cathode composite electrode was prepared by mixing the active material NCM (AM), conductive carbon additive (vapor-grown carbon nanofibers, VG-CNF), and solid electrolyte $\left(\mathrm{Li}_{6} \mathrm{PS}{ }_{5} \mathrm{Cl}, \mathrm{SE}\right.$, particle size 1-2 $\mu \mathrm{m}$ ) in the mass ratio of 85:13:2 with a blender (Klarstein) for $3 \mathrm{~min}$ and $10 \mathrm{~s}$. For the preparation of the powdered anode composite electrodes the active material (Si-C, SiNP, Si/C65), the VG-CNF and the SE (particle size 3-4 $\mathrm{mm}$ ) were mixed in the ratio of $60: 35: 5$ for $30 \mathrm{~min}$ in an agate mortar by hand.

The Si-C anodes used with liquid electrolyte were prepared based on a water based slurry. The slurry contained $80 \mathrm{wt} \% \mathrm{Si}-\mathrm{C}, 10 \mathrm{wt} \%$ multiwalled carbon nanotubes (MWCNT, Nanocyl7000, 90\%) and 10 wt\% styrenebutadiene rubber (SBR, Targray, 15\%) and was blended with a mixer mill (MM400, Retsch) at $25 \mathrm{~Hz}$ for $15 \mathrm{~min}$. After coating on a copper foil ( $9 \mu \mathrm{m})$ with an automatic film applicator (BYK), the coatings were dried at $80^{\circ} \mathrm{C}$ for $2 \mathrm{~h}$. The resulting $\mathrm{Si}-\mathrm{C}$ anodes have a density of $0.6 \mathrm{~g} \mathrm{~cm}^{-3}$ and a loading of $4.3-4.8 \mathrm{mg} \mathrm{cm}^{-2}$. 


\section{Preparation of a test cell}

Test cells were prepared in half- and full cell configurations for investigating the basic characteristics of cathode and anode such as the charge/discharge potential profiles, rate discharge capability and the cell internal resistance.

The ASSB cells were prepared by using a die with a diameter of $13 \mathrm{~mm}$ as described previously. ${ }^{[64]}$ The cell comprises of a stainless steel outer casing with a Teflon liner. For a typical test cell, $150 \mathrm{mg}(\sim 750 \mu \mathrm{m})$ of the electrolyte $\mathrm{Li}_{6} \mathrm{PS}{ }_{5} \mathrm{Cl}$ powder (particle size 3-4 $\mu \mathrm{m}$ ) was uniformly spread inside the die by a micro-spatula. Next, the powder was once temporally compressed and compacted into a pellet.

For half-cells, the anode composite powder (Si28@C, Si34@C, Si37@C, $\mathrm{Si} / \mathrm{C} 65$, SiNP) or cathode composite powder was homogeneously distributed across the compacted electrolyte surface in the die. Then the electrode layer was temporarily compressed. On the opposite side of the cell stack, a lithium or lithium-indium anode ( $\mathrm{Li}-\mathrm{In}$ ) was placed and compressed as described by Takada et al. ${ }^{[66]}$

For NCM|SE|Si-C full cells, 7.64 mg of the anode composite (Si37@C) and the respective amount of the cathode composite, according to the $n / p$ ratio $(1.1,1.3,1.7,2.0)$, were homogeneously distributed on opposite sides of the compacted electrolyte surface. For the balancing of the full cells, the first cycle practical specific lithiation capacity of the composite anode (922 $\mathrm{mAh} \mathrm{g}^{-1}$ ) and the first cycle practical specific discharge capacity of the cathode (176 mAh g$\left.{ }^{-1}\right)$, based on the half-cell characterization, were used for the calculation of the areal capacities and loadings.

Then, all the cell components were again pressed together and completely pelletized by using a hydraulic press ( $300 \mathrm{MPa}$ for $30 \mathrm{~s}$ were applied). After compression, the cell stack was placed inside the outer steel casing where a screw maintains the electric contact in the cell. The screw was fastened at $3.5 \mathrm{Nm}$ using a preset torque.

The Si-C electrodes used with liquid electrolyte in coin cells were dried at $80{ }^{\circ} \mathrm{C}$ under vacuum for $12 \mathrm{~h}$. For half-cells, the Si-C electrodes (diameter $12 \mathrm{~mm}$ ) were tested vs. a lithium anode $(99.9 \%$, diameter $16.5 \mathrm{~mm}, 250$ $\mu \mathrm{m}$ thick, MTI Corporation). The full cells contained a Si-C anode (diameter $16 \mathrm{~mm}$ ) and a NCM111 cathode (diameter $15 \mathrm{~mm}$ ). CR2016 coin cells (MTI Corp.) were assembled with the $\mathrm{Al}_{2} \mathrm{O}_{3}$ impregnated polyethylene terephthalate separator FS3002 by Freudenberg (diameter $19 \mathrm{~mm}, 22 \mu \mathrm{m}$ thick), a stainless steel spacer ( $1 \mathrm{~mm}$ thick) and $30 \mu \mathrm{l}$ (half-cells) or $50 \mu \mathrm{l}$ (full cells) LP30 + 10\% fluoroethylene carbonate (FEC). LP30 (99.9\%, Solvionic SA) contains $1 \mathrm{M}$ lithium hexafluorophosphate $\left(\mathrm{LiPF}_{6}\right)$ in 1:1 (v/v) ethylene carbonate and dimethyl carbonate.

All above mentioned processes were carried out in an Ar filled glove box (<0.1 ppm $\mathrm{H}_{2} \mathrm{O}$ and $\mathrm{O}_{2}$ ).

\section{Characterization}

The powder X-ray diffraction (XRD, CuKa, $40 \mathrm{kV}, 40 \mathrm{~mA}$ ) pattern was measured using a D5005 XRD system (Siemens, Germany) for verifying crystallinity of Si-C anodes and crystalline side products of the syntheses at room temperature.

Raman measurements were conducted to analyze the crystalline or amorphous Si-C anodes using a Raman microscope (micro-Raman Spectrometer, Renishaw inVia PLC) with an excitation laser wavelength of $514 \mathrm{~nm}$ and a 50x lens. The laser beam power at the specimen was $10 \%$ and the acquisition time was $5 \times 60 \mathrm{~s}$. For XRD and Raman measurements Kapton tape $(3 \mathrm{M})$ was used to prevent degradation due to moisture.

The scanning electron microscope (SEM) JSM-7800F from JEOL with an Upper Electron Detector (UED) inlense detector and $3 \mathrm{kV}$ acceleration voltage was used to analyze the structure of the different $\mathrm{Si}-\mathrm{C}$ and the SiNPs. The average size of the particles was determined by measuring the diameter of ten particles with the program ImageJ which then calculated the average value and the standard deviation. Transmission electron microscope (TEM) images of the Si-C were obtained with a JEM-2100 from JEOL (200 kV acceleration voltage).

To quantify the silicon content of the Si-C a Netzsch STA 409 PC/PG simultaneous thermal analyzer was used. A specific amount of a Si-C sample was heated under argon with $10 \mathrm{~K} \mathrm{~min}^{-1}$ to $500{ }^{\circ} \mathrm{C}$ and held for $30 \mathrm{~min}$ and heated again with $5 \mathrm{~K} \mathrm{~min}^{-1}$ to $1000^{\circ} \mathrm{C}$ and held for $30 \mathrm{~min}$. Assuming that the $\mathrm{Si}$ particles are fully oxidized to $\mathrm{SiO}_{2}$ due to the heat treatment the Si content can be calculated from the ratio between the mass of silicon and the mass of the sample. The mass of silicon is calculated from the mass of the $\mathrm{SiO}_{2}$ residue and the ratio between the molar masses of $\mathrm{Si}$ and $\mathrm{SiO}_{2}$. The average value of three measurements for each sample was determined.

The investigation of the voltage profiles, rate and cycle stability of the halfand full cells via galvanostatic cycling with potential limitation (GCPL) were conducted with a battery tester CTS-lab (BaSyTec, Germany) at $25^{\circ} \mathrm{C}$. Cyclic voltammetry (CV) and electrochemical impedance (EIS) were measured with a VMP-3 (Bio-Logic, France) controlled by a computer. The EIS measurements were conducted with an amplitude of $10 \mathrm{mV}$ in a frequency range of $0.1 \mathrm{~Hz}-1 \mathrm{MHz}$ at $25^{\circ} \mathrm{C}$.

Keywords: all-solid-state battery $\cdot$ balancing $\cdot$ nanostructures $•$ silicon carbon composites $\bullet$ thiophosphate solid electrolyte

[1] a) D. Larcher, J.-M. Tarascon, Nat. chem. 2015, 7, 19; b) T. Pohl, G Heweling, C. Fischer, K. Weber, Int. J. Environ. Sci. 2017, 2, 410.

[2] D. Andre, S.-J. Kim, P. Lamp, S. F. Lux, F. Maglia, O. Paschos, B. Stiaszny, J. Mater. Chem. A 2015, 3, 6709.

[3] N. Nitta, F. Wu, J. T. Lee, G. Yushin, Mater. Today (Oxford, U. K.) 2015 18, 252.

[4] X. Su, Q. Wu, J. Li, X. Xiao, A. Lott, W. Lu, B. W. Sheldon, J. Wu, Adv. Energy Mater. 2014, 4, 1300882.

[5] R. Schmuch, R. Wagner, G. Hörpel, T. Placke, M. Winter, Nat. Energy 2018, 3, 267.

[6] H. Wu, Y. Cui, Nano Today 2012, 7, 414

[7] L. Li, S. Li, Y. Lu, Chem. Commun. (Cambridge, U. K.) 2018, 54, 6648.

[8] J. Wang, T. Xu, X. Huang, H. Li, T. Ma, RSC Adv. 2016, 6, 87778.

[9] X. Zhang, D. Kong, X. Li, L. Zhi, Adv. Funct. Mater. 2019, 29, 1806061.

[10] a) L. Baggetto, R. A. H. Niessen, F. Roozeboom, P. H. L. Notten, Adv. Funct. Mater. 2008, 18, 1057; b) Y. S. Jung, D. Y. Oh, Y. J. Nam, K. H Park, Isr. J. Chem. 2015, 55, 472

[11] J. Janek, W. G. Zeier, Nat. Energy 2016, 1, 1167.

[12] N. Liu, W. Li, M. Pasta, Y. Cui, Front. Phys. 2014, 9, 323

[13] a) F. Han, A. S. Westover, J. Yue, X. Fan, F. Wang, M. Chi, D. N. Leonard, N. J. Dudney, H. Wang, C. Wang, Nat. Energy 2019, 4, 187; b) F. Han J. Yue, X. Zhu, C. Wang, Adv. Energy Mater. 2018, 8, 1703644.

[14] T. Krauskopf, H. Hartmann, W. G. Zeier, J. Janek, ACS Appl. Mater Interfaces 2019, 11, 14463.

[15] Y.-G. Lee, S. Fujiki, C. Jung, N. Suzuki, N. Yashiro, R. Omoda, D.-S. Ko, T. Shiratsuchi, T. Sugimoto, S. Ryu J. H. Ku, T. Watanabe, Y. Park, Y. Aihara, D. Im, I. T. Han, Nat. Energy 2020, 3, 267.

[16] D. Ma, Z. Cao, A. Hu, Nano-Micro Lett. 2014, 6, 347.

[17] a) N. Nitta, G. Yushin, Part. Part. Syst. Charact. 2014, 31, 317; b) M. N Obrovac, L. Christensen, Electrochem. Solid-State Lett. 2004, 7, A93.

[18] A. Baasner, F. Reuter, M. Seidel, A. Krause, E. Pflug, P. Härtel, S. Dörfler, T. Abendroth, H. Althues, S. Kaskel, J. Electrochem. Soc. 2020, 167, 20516.

[19] M. Slovick, "Tesla Battery Day - Taking EVs to the Next Level", can be found under https://www.electronicdesign.com/markets/automotive/ article/21143628/tesla-battery-daytaking-evs-to-the-next-level, 2020.

[20] M. Ashuri, Q. He, L. L. Shaw, Nanoscale 2016, 8, 74.

[21] X. H. Liu, L. Zhong, S. Huang, S. X. Mao, T. Zhu, J. Y. Huang, ACS nano 2012, 6, 1522 
[22] a) J. Xu, Q. Zhang, Y.-T. Cheng, J. Electrochem. Soc. 2016, 163, A401 A405; b) M. Ge, J. Rong, X. Fang, A. Zhang, Y. Lu, C. Zhou, Nano Res 2013, 6, 174.

[23] a) V. Chakrapani, F. Rusli, M. A. Filler, P. A. Kohl, J. Power Sources 2012, 205, 433; b) H. Chen, Y. Xiao, L. Wang, Y. Yang, J. Power Sources 2011, 196, 6657 .

[24] C. K. Chan, H. Peng, G. Liu, K. Mcllwrath, X. F. Zhang, R. A. Huggins, Y. Cui, Nat. Nanotechnol. 2008, 3, 31.

[25] a) A. T. Tesfaye, R. Gonzalez-Rodriguez, J. L. Coffer, T. Djenizian, ECS Trans. 2017, 77, 349; b) J. Ha, U. Paik, J. Power Sources 2013, 244 463; c) H. Wu, G. Chan, J. W. Choi, I. Ryu, Y. Yao, M. T. McDowell, S. W. Lee, A. Jackson, Y. Yang, L. Hu, Y. Cui, Nat. Nanotechnol. 2012, 7, 310.

[26] a) J. W. Wang, Y. He, F. Fan, X. H. Liu, S. Xia, Y. Liu, C. T. Harris, H. Li, J. Y. Huang, S. X. Mao, T. Zhu, Nano Lett. 2013, 13, 709; b) C. Yu, X. Li, T. Ma, J. Rong, R. Zhang, J. Shaffer, Y. An, Q. Liu, B. Wei, H. Jiang, Adv. Energy Mater. 2012, 2, 68.

[27] M. Piwko, S. Thieme, C. Weller, H. Althues, S. Kaskel, J. Power Sources 2017, 362, 349.

[28] S. Cangaz, F. Hippauf, F. S. Reuter, S. Doerfler, T. Abendroth, H. Althues, S. Kaskel, Adv. Energy Mater. 2020, 3, 2001320.

[29] a) S. Chen, M. L. Gordin, R. Yi, G. Howlett, H. Sohn, D. Wang, Phys. Chem. Chem. Phys. 2012, 14, 12741; b) G.X. Wang, J.H. Ahn, J. Yao, S. Bewlay, H.K. Liu, Electrochem. Commun. 2004, 6, 689; c) N. Liu, H. Wu, M. T. McDowell, Y. Yao, C. Wang, Y. Cui, Nano Lett. 2012, 12, 3315 d) W. Wang, I. Ruiz, K. Ahmed, H. H. Bay, A. S. George, J. Wang, J. Butler, M. Ozkan, C. S. Ozkan, Small 2014, 10, 3389; e) T. Mori, C.-J. Chen, T.-F. Hung, S. G. Mohamed, Y.-Q. Lin, H.-Z. Lin, J. C. Sung, S.-F. Hu, R.-S. Liu, Electrochim. Acta 2015, 165, 166.

[30] a) J. Shi, L. Zu, H. Gao, G. Hu, Q. Zhang, Adv. Funct. Mater. 2020, 13, 2002980; b) K. McCormac, I. Byrd, R. Brannen, B. Seymour, J. Li, J. Wu, Phys. Status Solidi A 2015, 212, 877.

[31] a) B. D. Polat, O. Keles, J. Alloys Compd. 2015, 622, 418; b) X. Wang, L. Sun, X. Hu, R. A. Susantyoko, Q. Zhang, J. Power Sources 2015, 280 393.

[32] Y. Yao, N. Liu, M. T. McDowell, M. Pasta, Y. Cui, Energy Environ. Sci. 2012, 5, 7927.

[33] a) L. Chen, K. Wang, X. Xie, J. Xie, Electrochem. Solid-State Lett. 2006, 9, A512; b) H. Guo, H. Zhao, C. Yin, W. Qiu, Mater. Sci. Eng., B 2006 131, 173; c) I. Kovalenko, B. Zdyrko, A. Magasinski, B. Hertzberg, Z. Milicev, R. Burtovyy, I. Luzinov, G. Yushin, Science 2011, 334, 75.

[34] a) S. Dalavi, P. Guduru, B. L. Lucht, J. Electrochem. Soc. 2012, 159, A642-A646; b) A. M. Haregewoin, A. S. Wotango, B.-J. Hwang, Energy Environ. Sci. 2016, 9, 1955.

[35] X. Huang, J. Solid State Electrochem. 2011, 15, 649

[36] C. Cao, Z.-B. Li, X.-L. Wang, X.-B. Zhao, W.-Q. Han, Front. Energy Res. 2014, 2, 947.

[37] J. Sakabe, N. Ohta, T. Ohnishi, K. Mitsuishi, K. Takada, Commun. Chem 2018, 1, 13

[38] R. Miyazaki, N. Ohta, T. Ohnishi, I. Sakaguchi, K. Takada, J. Power Sources 2014, 272, 541.

[39] R. Okuno, M. Yamamoto, Y. Terauchi, M. Takahashi, Energy Procedia 2019, 156, 183.

[40] N. Ohta, S. Kimura, J. Sakabe, K. Mitsuishi, T. Ohnishi, K. Takada, ACS Appl. Energy Mater. 2019, 2, 7005.

[41] J. C. Bachman, S. Muy, A. Grimaud, H.-H. Chang, N. Pour, S. F. Lux, O. Paschos, F. Maglia, S. Lupart, P. Lamp, L. Giordano, Y. Shao-Horn, Chem. Rev. (Washington, DC, U. S.) 2016, 116, 140.

[42] A. Sakuda, A. Hayashi, M. Tatsumisago, Curr. Opin. Electrochem. 2017, 6, 108.

[43] K.-B. Kim, N. A. Dunlap, S. S. Han, J. J. Jeong, S. C. Kim, K. H. Oh, S.H. Lee, J. Electrochem. Soc. 2018, 165, A1903-A1908.

[44] A. Baasner, S. Dörfler, M. Piwko, S. Desilani, J. Brückner, H. Althues, S. Kaskel, J. Mater. Chem. A 2018, 6, 14787.

[45] H. Xu, B. Gao, H. Cao, X. Chen, L. Yu, K. Wu, L. Sun, X. Peng, J. Fu, J. Nanomater. 2014, 2014, 1.

[46] B. Li, D. Yu, S.-L. Zhang, Phys. Rev. B 1999, 59, 1645.

[47] A. Käppler, F. Windrich, M. G. J. Löder, M. Malanin, D. Fischer, M. Labrenz, K.-J. Eichhorn, B. Voit, Anal. Bioanal. Chem. 2015, 407, 6791.
[48] a) L. Zou, B. Huang, Y. Huang, Q. Huang, C.'a. Wang, Mater. Chem. Phys. 2003, 82, 654; b) A. C. Ferrari, Solid State Commun. 2007, 143, 47.

[49] J. Li, J. R. Dahn, J. Electrochem. Soc 2007, 154, A156.

[50] K. Ogata, E. Salager, C. J. Kerr, A. E. Fraser, C. Ducati, A. J. Morris, S. Hofmann, C. P. Grey, Nat. Commun. 2014, 5, 3217.

[51] M. N. Obrovac, V. L. Chevrier, Chem. Rev. (Washington, DC, U. S.) 2014, 114, 11444.

[52] K. O. Bugaev, A. A. Zelenina, V. A. Volodin, Int. J. Spectrosc. 2012, 2012, 1.

[53] S. Boulineau, M. Courty, J.-M. Tarascon, V. Viallet, Solid State Ionics 2012, 221, 1 .

[54] a) M. D. Levi, D. Aurbach, J. Phys. Chem. B 1997, 101, 4630; b) B. Markovsky, M. D. Levi, D. Aurbach, Electrochim. Acta 1998, 43, 2287.

[55] T. D. Hatchard, J. R. Dahn, J. Electrochem. Soc. 2004, 151, A838.

[56] X. Xiao, W. Zhou, Y. Kim, I. Ryu, M. Gu, C. Wang, G. Liu, Z. Liu, H. Gao, Adv. Funct. Mater. 2015, 25, 1426.

[57] C. Chen, T. Zhou, D. L. Danilov, L. Gao, S. Benning, N. Schön, S. Tardif, H. Simons, F. Hausen, T. U. Schülli, R.-A. Eichel, P. H. L. Notten, Nat. Commun. 2020, 11, 3283.

[58] J. Kasnatscheew, T. Placke, B. Streipert, S. Rothermel, R. Wagner, P. Meister, I. C. Laskovic, M. Winter, J. Electrochem. Soc. 2017, 164, A2479-A2486.

[59] F. Reuter, A. Baasner, J. Pampel, M. Piwko, S. Dörfler, H. Althues, S. Kaskel, J. Electrochem. Soc. 2019, 166, A3265-A3271.

[60] S. D. Beattie, M. J. Loveridge, M. J. Lain, S. Ferrari, B. J. Polzin, R Bhagat, R. Dashwood, J. Power Sources 2016, 302, 426

[61] J. Kasnatscheew, M. Evertz, B. Streipert, R. Wagner, S. Nowak, I. Cekic Laskovic, M. Winter, J. Phys. Chem. C 2017, 121, 1521.

[62] H.-J. Noh, S. Youn, C. S. Yoon, Y.-K. Sun, J. Power Sources 2013, 233, 121.

[63] a) J. Kasnatscheew, R. Wagner, M. Winter, I. Cekic-Laskovic, Top. Curr. Chem. 2018, 376, 16; b) A. O. Kondrakov, H. Geßwein, K. Galdina, L. de Biasi, V. Meded, E. O. Filatova, G. Schumacher, W. Wenzel, P. Hartmann, T. Brezesinski, J. Janek, J. Phys. Chem. C 2017, 121, 24381.

[64] S. Ito, S. Fujiki, T. Yamada, Y. Aihara, Y. Park, T. Y. Kim, S.-W. Baek, J.-M. Lee, S. Doo, N. Machida, J. Power Sources 2014, 248, 943.

[65] P. R. Rayavarapu, N. Sharma, V. K. Peterson, S. Adams, J. Solid State Electrochem. 2012, 16, 1807.

[66] K. Takada, Solid State lonics 1996, 86-88, 87 
ARTICLE 